\title{
IMPLEMENTASI CONTENT BASED IMAGE RETRIEVAL (CBIR) PADA CITRA BATIK BESUREK YANG TIDAK UTUH MENGGUNAKAN METODE SPEEDED UP ROBUST FEATURES (SURF) DAN FAST LIBRARY APPROXIMATED NEAREST NEIGHBOR (FLANN)
}

\author{
Rezki Oksaputri ${ }^{1}$, Ernawati $^{2}$, Desi Andreswari ${ }^{3}$ \\ 1,2,3 Program Studi Informatika, Fakultas Teknik, Universitas Bengkulu \\ Jl. WR. Supratman Kandang Limun Bengkulu 38371A INDONESIA \\ (telp: 0736-341022; fax: 0736-341022) \\ ${ }^{1}$ rezkioksaputri24@gmail.com \\ 2ernawatieunib.ac.id \\ ${ }^{3}$ desi.andreswarieunib.ac.id
}

\begin{abstract}
Abstrak: Pengenalan citra dengan menggunakan citra batik besurek memiliki kelemahan yaitu kadang kala citra batik besurek yang ingin diproses merupakan citra yang tidak utuh atau tidak sesempurna citra asli yang berada didalam database. Berdasarkan permasalah tersebut, maka dilakukan penelitian untuk memproses temu kembali citra batik besurek yang tidak utuh menggunakan metode speeded up robust features (SURF) untuk proses ekstraksi keypoint pada citra dan fast library approximated nearest neighbor (FLANN) untuk proses matching-nya. Adapaun tujuan dari penelitian yang akan dilakukan adalah untuk mengetahui persentase citra yang dapat dikenali dengan menggunakan metode SURF dan FLANN. Pada penelitian ini digunakan 67 citra batik besurek dengan motif kaligrafi, raflesia, kaligrafi dan raflesia, burung kuau dan raflesia, burung kuau, dan rembulan. Kondisi citra yang digunakan pada pengujian adalah citra yang ditutupi dari 10\% hingga 90\% dan citra yang diambil dengan sudut pengambilan yang tidak baik. Pada penelitian ini digunakan nilai recall, precision, dan akurasi untuk mengetahui keberhasilan metode SURF dan FLANN dalam mengenali citra batik besurek yang tidak utuh. Penelitian ini mendapatkan hasil bahwa metode SURF dan FLANN dapat mengenali citra batik besurek yang ditutupi hingga 90\% serta didapatkan nilai recall tertinggi adalah $100 \%$ pada motif rembulan, precision tertinggi adalah $78,82 \%$ pada motif kaligrafi dan raflesia, dan akurasi tertinggi adalah $86,1 \%$ pada motif rembulan.
\end{abstract}

Kata Kunci: batik besurek, content based image retrieval (CBIR), speeded up robust fetures (SURF), fast library approximated nearest neighbor (FLANN)

Abstract: Retrieval image by using an image of batik besurek have the weakness that sometimes batik besurek image that wants to be processed image that is not complete or not as perfect as original image residing in the database. The purpose of this research is to know the percentage of the image that can be recognized by using SURF and FLANN method. In this research used 67 images of batik besurek with motifs of calligraphy, raflesia, calligraphy and raflesia, burung kuau and raflesia, burung kuau, and rembulan. Query image condition used in the test is the image covered from $10 \%$ to $90 \%$ as many as 54 images, the image taken with the angle of shooting is not good as much as 3 images, the image comes from a patchwork of 5 pieces, and the image taken with the camera application of 3 pieces. In this research used the value of recall, precision, and accuracy to determine the success of SURF and FLANN methods in recognizing the image of batik besurek that is complete. This research got the 
Jurnal Pseudocode, Volume V Nomor 2, September 2018, ISSN 2355-5920

www.ejournal.unib.ac.id/index.php/pseudocode

result that SURF and FLANN method can recognize batik besurek image covered up to $90 \%$ and get the highest recall value is $100 \%$ at moon motif, the highest precision is $78,82 \%$ on motif of calligraphy and raflesia, and highest accuracy is $86,1 \%$ on the rembulan motif.

Keywords : batik besurek, content based image retrieval (CBIR), speeded up robust fetures (SURF), fast library approximated nearest neighbor (FLANN)

\section{PENDAHULUAN}

Batik besurek merupakan salah satu warisan budaya dari Kota Bengkulu yang dikenal sebagai Kota Gading Cempaka. Batik besurek memiliki karakteristik yang unik. Karakteristik batik besurek dilihat dari motif batik besurek itu sendiri, misalnya motif batik besurek motif burung kuau memiliki karakteristik yang berbeda dengan batik besurek motif kaligrafi. Dengan karakteristik ini dapat dibedakan jenis batik besurek. Pengenalan citra batik besurek dapat dilakukan dengan pengolahan citra digital dengan menggunakan karakteristik pada masing-masing batik besurek.

Namun, pengenalan citra batik besurek dengan melihat karakteristik citra ini memiliki kelemahan yaitu kadang kala citra batik besurek yang ingin diproses merupakan citra yang tidak utuh (bukan citra yang mengandung noise, gelap, atau silau), hal ini dapat disebabkan karena objek lain yang menutupi, pengambilan gambar yang tidak sempurna, atau keadaan objek itu sendiri yang mengalami perubahan (objek diperbesar, diperkecil, atau diputar). Hal ini menyebabkan karakteristik batik besurek yang ada pada citra batik besurek tersebut akan mengalami perubahan karena terdapat karakteristik yang hilang, sehingga dapat menyebabkan hasil pengenalan citra menggunakan citra batik besurek tersebut tidak sesuai dengan hasil yang diinginkan.

Untuk menghindari kelemahan ini, maka dilakukan penelitian yang berdasarkan pada content based image retrieval (CBIR) dimana CBIR ini merupakan proses untuk melakukan pencarian citra digital pada suatu database citra. Yang dimaksud dengan "Content Based" di sini adalah: objek yang dianalisa dalam proses pencarian itu adalah actual contents (kandungan aktual) sebuah citra. Istilah konten pada konteks ini merujuk pada warna, bentuk, tekstur, atau informasi lain yang didapatkan dari citra tersebut [1].

\section{LANDASAN TEORI}

\section{A. Batik Besurek}

Provinsi Bengkulu merupakan salah satu kawasan yang berada di wilayah Sumatera. Nama Bengkulu sebagai wilayah penghasil batik belum terkenal secara luas. Namun, provinsi dengan ibu kota Bengkulu ini memiliki ciri khas batik yang tidak kalah mutunya dari batik hasil daerah lainnya. Batik Bengkulu tersebut bernama batik besurek [2].

Kain Batik Besurek adalah batik tulis tradisional khas Bengkulu yang termasuk batik pesisir dengan motif dominan kaligrafi Arab dihiasi perpaduan flora dan fauna yang sarat akan makna simbolis, melambangkan hubungan manusia dan alam dengan sang pencipta. Besurek (surat) berarti menulis atau melukis kaligrafi dan relief alam pada bidang kain, yang digunakan untuk kebutuhan sandang dalam tradisi masyarakat Bengkulu. Warna dasar yang dominan kain besurek adalah merah, biru, coklat dan kuning sesuai dengan kebutuhan dan penggunaanya [3]. Batik Besurek memiliki motif yang beragam. Mulai dari motif kaligrafi, bunga raflesia, burung kuau, relung paku, dan rembulan [4]. 
Jurnal Pseudocode, Volume V Nomor 2, September 2018, ISSN 2355-5920

www.ejournal.unib.ac.id/index.php/pseudocode

\section{B. Speeded Up Robust Features (SURF)}

Metode Speeded Up Robust Features (SURF) merupakan sebuah metode deteksi fitur yang menggunakan keypoint dari sebuah citra/gambar. Keypoint itu sendiri adalah bagian-bagian dari sebuah citra/gambar yang nilainya kuat/tetap ketika mengalami perubahan skala, rotasi, blurring, transformasi 3 dimensi, pencahayaan dan juga perubahan bentuk. Perubahan bentuk itu bisa terjadi karena bentuk citra data awal yang tidak utuh atau tidak sempurna gambar yang ada di dalam citra sampel tersebut. Citra uji yang tidak utuh mungkin karena ada objek lain yang menutupi, atau pengambilan gambar yang tidak sempurna, atau keadaan objek itu sendiri yang telah mengalami perubahan [5].

\section{Ruang Skala (Scale Space)}
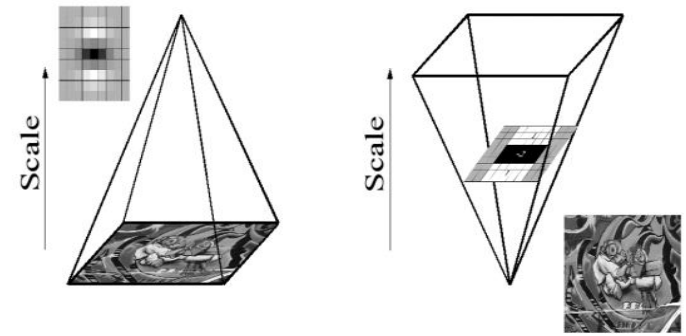

Gambar 1. Representasi Ruang Skala (Scale Space)

Dengan ukuran citra yang berbeda-beda, akan sangat sulit bagi kita untuk membandingkan fiturfitur yang terdapat pada citra tersebut. Oleh sebab itu, diperlukan suatu proses yang menangani perbedaan ukuran dengan menggunakan metode perbandingan skala. Dalam metode ini, kita menggunakan ruang skala di mana citra diimplementasikan dalam bentuk sebuah image pyramid (Gambar 1.). Citra secara berulang akan diperhalus (smoothing) dengan fungsi Gaussian dan secara beruntun dengan cara subsampling untuk mencapai tingkat tertinggi pada piramida. Dengan menggunakan integral image, perhitungan ini tidak perlu dilakukan secara iteratif dengan menggunakan filter yang sama, tetapi dapat filter dengan ukuran sembarang ke dalam beberapa skala citra yang berbeda [6].

\section{Lokalisasi Keypoint}

Untuk mencari lokasi keypoint yang invariant terhadap rotasi maka dilakukan proses yang terdiri dari tiga langkah, yaitu [7]: Menentukan nilai ambang (threshold) penentuan lokasi. Ketika nilai ambang dinaikkan, jumlah keypoint yang terdeteksi lebih kecil dan sebaliknya. Oleh karena itu, nilai ambang bisa disesuaikan untuk setiap aplikasi. Langkah selanjutnya adalah proses nonmaxima suppression yaitu proses yang bertujuan untuk mencari sekumpulan calon keypoint. Proses ini dilakukan dengan membandingkan setiap pixel citra pada scale space dengan 26- Neighbors, yang terdiri atas 8 titik di scale asli dan 9 di setiap scale atas dan bawahnya (total keseluruhan 9+8+9=26Neighbors). Hasil dari non-maxima suppression adalah keypoint yang dihasilkan citra.

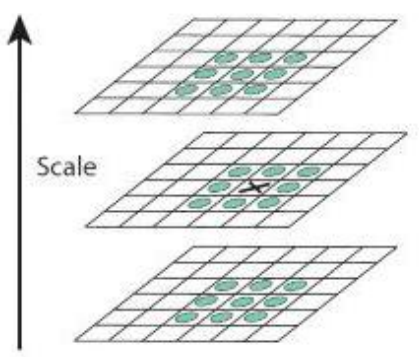

Gambar 2. Non Maxima Suppression

Proses terakhir adalah proses pencarian keypoint dengan menggunakan interpolasi dengan data yang dekat dengan keypoint. Ini dilakukan dengan mencocokan quadratic 3 dimensi. untuk mendapatkan interpolasi data maksimal, maka digunakan pendekatan Taylor Expansion $\mathrm{H}(\mathrm{x}, \mathrm{y}, \sigma)$ seperti pada persamaan 2.1. [8]:

$$
D(x)=D+\frac{\partial D^{T}}{\partial x} x+\frac{1}{2} x^{T} \frac{\partial^{2} D}{\partial x^{2}} x
$$


Jurnal Pseudocode, Volume V Nomor 2, September 2018, ISSN 2355-5920 www.ejournal.unib.ac.id/index.php/pseudocode

Dengan $x$ adalah vektor dan D memetakan $x$ ke skalar. Lokasi ekstrim yang diinterpolasi, $\hat{x}=(\mathrm{x}$, $\mathrm{y}, \mathrm{s}$ ), ditemukan dengan mencari turunan dari fungsi diatas dan diberi nilai nol, sehingga [8]:

$$
\hat{\mathrm{x}}=-\frac{\partial^{2} D^{-1}}{\partial x^{2}} \frac{\partial D}{\partial x}
$$

Jika $\hat{x}$ lebih besar dari 0.5 pada $\mathrm{x}, \mathrm{y}$ atau arah $\sigma$, lokasi perlu disesuaikan lagi dengan melakukan interpolasi kembali. Prosedur ini diulang sampai nilai $\hat{\mathrm{x}}$ kurang dari 0.5 . Bila interpolasi telah dilakukan beberapa kali tetapi hasilnya tidak memenuhi nilai dibawah 0.5, maka keypoint tersebur dihapus. Keypoint yang tersisa adalah yang stabil [8].

\section{Deskriptor Keypoint dan Proses Matching}

Deskriptor ditentukan berdasarkan daerah pixel sekitar keypoint. Deskriptor ini menggambarkan distribusi intensitas pixel tetangga disekitar keypoint, informasi gradien yang di ekstrak Pada SURF dihitung distribusi respon wavelet Haar order pertama dalam arah $x$ dan arah y. Selain itu, SURF menggunakan integral gambar untuk meningkatkan kecepatan proses. Hal tersebut bertujuan untuk mengurangi waktu komputasi pada ekstraksi fitur dan pada proses matching fitur, yang juga telah terbukti meningkatkan robust [6].

Proses awal yang dilakukan adalah mencocokkan orientasi yang dihasilkan berdasarkan informasi dari daerah yang berbentuk lingkaran disekitar piksel yang menjadi keypoint. Kemudian membuat daerah berbentuk kotak pada orientasi yang terpilih dan mengekstrak deskriptor SURF dari daerah tersebut. Pada proses selanjutnya, proses matching fitur antara dua gambar dilakukan. Berikut ini dua langkah perhitungan deskriptor keypoint:

\section{Pembuatan Orientasi}

Pembuatan orientasi dilakukan dengan menghitung respon Haar wavelet dalam arah $\mathrm{x}$ dan arah y pada daerah pixel tetangga disekitar keypoint yang berbentuk lingkaran dengan jarak $6 s$, dimana $s$ adalah scale dari keypoint yang dideteksi. Ukuran wavelet ditentukan menjadi $4 s$. Filtering dipercepat prosesnya menggunakan integral gambar, dan keluaran yang dihasilkan direpresentasikan sebagai titik-titik pada ruang dengan respon horizontal sepanjang sumbu axis dan juga respon vertikal sepanjang sumbu koordinat. Orientasi dominan dihitung menggunakan jumlah semua respon dalam pergeseran orientasi dengan ukuran window $\pi / 3$ seperti pada Gambar 3, kemudian respon horizontal dan vertikal dalam window tersebut dijumlahkan. Dari kedua respon yang dijumlahkan sehingga menghasilkan sebuah vektor orientasi lokal. Vektor terpanjang inilah yang merupakan orientasi keypoint [9].

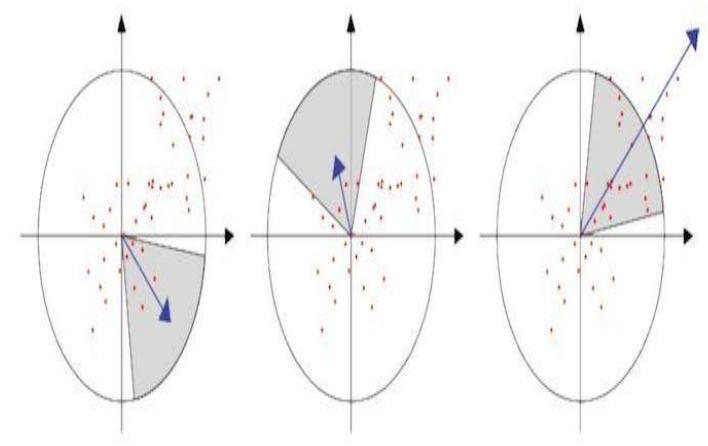

Gambar 3. Jendela Pergeseran Orientasi

\section{Deskriptor Berdasarkan Jumlah Respn Haar}

Wavelet

Untuk proses ekstraksi deskriptor, langkah pertama yang dilakukan adalah membuat daerah kotak sekitar keypoint, dimana keypoint sebagai pusat dari daerah kotak tersebut, dan orientasinya di sekitar orientasi yang ditentukan. Berikut ini 
Jurnal Pseudocode, Volume V Nomor 2, September 2018, ISSN 2355-5920 www.ejournal.unib.ac.id/index.php/pseudocode

merupakan gambar jendela orientasi perhitungan deskriptor pada skala yang berbeda [7] :

Pada tahap selanjutnya, respon wavelet $\mathrm{dx}$ dan dy dijumlahkan masing- masing sub-region. Selain memberikan informasi tentang polar dari perubahan intensitas, juga akan dihasilkan jumlah nilai absolut dari respon $|d x|$ dan $|d y|$. Masingmasing sub-region mempunyai empat dimensi deskriptor vektor $v$, yaitu $d x, d y,|d x|$ dan $|d y|$. Untuk $4 \times 4$ sub-region, maka panjang vektor deskriptornya adalah 64 sebagaimana di ilustrasikan pada Gambar 4 berikut ini [7]:

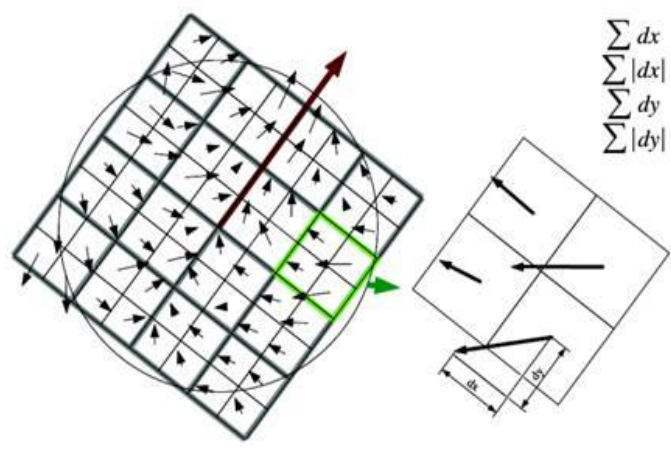

Gambar 4. Perhitungan Deskriptor

Sementara untuk mendapatkan hasil vektor $v$ dapat dilihat pada persamaan berikut ini [7]:

$$
v=\left(\sum d_{x}, \sum d_{y}, \sum\left|d_{x}\right|, \sum\left|d_{y}\right|,\right)
$$

\section{E. Fast Library Approximated Nearest Neighbor} (FLANN)

Metode Fast Library Approximated Nearest Neighbor (FLANN) adalah sebuah library untuk melakukan pencarian cepat, perkiraan piksel tetangga, yang terdapat pada space dimensi yang tinggi. Library ini merupakan kumpulan algoritma yang bekerja dengan baik untuk menemukan nilai tetangga terdekat, sementara untuk hasil parameter yang optimal, tergantung pada kumpulan data yang digunakan [7].

Metode FLANN ini digunakan untuk matching fitur SURF. Fitur SURF ini terdiri dari keypoint dan deskriptor yang berupa vektor. Untuk satu gambar di basis data terdapat banyak cluster untuk masing-masing fitur SURF. Cluster ini dibuat otomatis dengan $K$ - Nearest Neighbor (KNN) menggunakan tipe indeks $\mathrm{kd}$ tree, dimana $K$ Nearest Neighbor (KNN) ini akan mencari jarak terkecil antara vektor fitur dengan vektor pada cluster. Proses pencocokan fitur pada gambar query dan fitur pada gambar dalam basis data, vektor keypoint dan deskriptor pada gambar query akan dicocokkan nilainya menggunakan KNN search.

KNN search akan mencari cluster pada basis data yang nilai vektor deskriptornya paling dekat jaraknya dengan vektor deskriptor pada gambar query. Setelah cluster didapat, kemudian akan dicari nilai vektor deskriptor pada cluster tersebut yang sama atau paling dekat dengan vektor deskriptor pada gambar query. Jika terdapat yang sama, maka ada satu keypoint yang cocok antara kedua citra tersebut. Selanjutnya, untuk masingmasing gambar akan ditarik suatu garis dari satu titik ke titik lainnya yang memiliki nilai keypoint yang cocok. [9].

\section{Rasio Jarak}

Banyak fitur dari gambar tidak memiliki kecocokan yang benar dengan citra batik besurek yang ada pada database hal ini terjadi karena gambar yang tidak baik atau karena tidak terdeteksi pada dengan citra batik besurek yang ada pada database. Oleh karena itu, sangat berguna untuk memiliki cara untuk membuang fitur yang tidak sesuai dengan citra database. Perkiraan yang lebih baik adalah dengan membandingkan jarak tetangga terdekat dengan tetangga terdekat kedua. Perkiraan ini memiliki performa yang baik karena kecocokan benar yang cocok harus memiliki tetangga yang secara 
Jurnal Pseudocode, Volume V Nomor 2, September 2018, ISSN 2355-5920

www.ejournal.unib.ac.id/index.php/pseudocode

signifikan lebih dekat daripada kecocokan salah terdekat untuk mencapai pencocokan yang lebih baik. Pada penelitian David G. Lowe, yang mendapatkan hasil bahwa untuk kecocokan yang benar dan salah ditunjukkan dalam rasio yang terdekat dengan tetangga terdekat kedua dari masing-masing keypoint, penelitiannya menolak semua kecocokan di mana rasio jarak lebih besar dari 0,8 yang menghilangkan $90 \%$ kecocokan salah saat membuang kurang dari $5 \%$ dari kecocokan yang benar [8].

Jadi untuk deskriptor $X$, dicari deskriptor terdekat $\mathrm{X}_{1}$ dan deksriptor terdekat $X_{2}$. rasio jarak dari $d\left(X, X_{1}\right)$ dan $0.8^{*} d\left(X, X_{2}\right)$ maka dapat diterima bahwa deskriptor tersebut memiliki kecocokan yang benar.

\section{METODOLOGI}

Pengujian pada penelitian ini menggunakan 67 citra batik besurek di dalam database dan 65 citra uji yang terdiri dari 56 citra batik besurek yang berasal dari 6 motif batik besurek yaitu motif kaligrafi, raflesia, kaligrafi dan raflesia, burung kuau, burung kuau dan raflesia, dan rembulan dimana setiap citra batik besurek ditutupi dari $10 \%$ hingga 90\%, 5 citra yang berasal dari kain perca, 3 citra yang diambil dengan miring (pengambilan yang tidak sempurna) dan 3 citra yang diambil dari kamera aplikasi.

Digunakan nilai recall, precision dan akurasi untuk mengetahui tingkat keberhasilan aplikasi, recall digunakan untuk mengukur perbandingan jumlah citra uji relevan yang ditemukembalikan terhadap seluruh citra database yang relevan. Persmanaan untuk mencari nilai recall dapat dilihat pada persamaan (4)

$$
\text { Recall }=\frac{|R a|}{|R|}
$$

Precision digunakan unutk mengukur perbandingan citra uji relevan yang ditemukembalikan dengan banyak citra yang ditemukembalikan. Persmanaan untuk mencari nilai precision dapat dilihat pada persamaan (5).

$$
\text { Precision }=\frac{|R a|}{|A|}
$$

Akurasi merupakan tingkat kedekatan antara nilai prediksi dengan nilai aktual, yang dapat didefinisikan pada matriks confusion pada Tabel 1 .

Tabel 1. Matriks Confusion

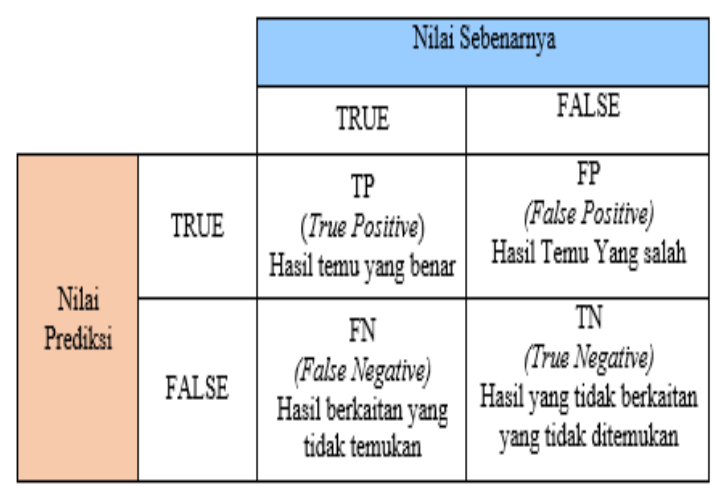

Persmanaan untuk mencari nilai precision dapat dilihat pada persamaan (6).

$$
\text { Akurasi }=\frac{T P+T N}{T P+T N+F P+F N}
$$

Keterangan :

$R a=$ citra yang relevan yang ditemukan

$R=$ citra yang relevan dalam database

$A=$ Jumlah citra yang ditemukembalikan

$T P=$ True Positive

TN = True Negative

$F P=$ False Positive

$F N=$ False Negative

\section{ANALISIS DAN PERANCANGAN}

Alur sistem merupakan analisis tahapan kerja sistem yang akan dibangun. Alur ini dimulai dari pengguna memasukkan input-an berupa citra batik besurek yang tidak utuh sampaai dengan menghasilkan keluaran berupa citra batik besurek 
Jurnal Pseudocode, Volume V Nomor 2, September 2018, ISSN 2355-5920

www.ejournal.unib.ac.id/index.php/pseudocode

hasil proses pengenalan.Secara garis besar alur sisem yang akan dibangun dapat dilihat pada Gambar 5.

Proses dimulai ketika menginputkan citra batik besurek, kemudian citra batik besurek tersebut akan diubah menjadi citra grayscale. Citra grayscale batik besurek tersebut akan diekstraksi keypoint-nya dengan metode SURF, hasil proses ini berupa deskriptor, yakni keypoint yang telah dideskripsikan. Citra batik besurek yang ada di dalam database akan diubah menjadi citra grayscale kemudian akan diekstraksi keypoint-nya dengan metode SURF. Hasil proses ekstraksi ini berupa deskriptor yang kemudian deskriptor pada setiap citra akan digabungkan kedalam sebuah matriks. Setelah itu akan dilakukan proses matching pada deskriptor citra uji dan deskriptor citra di dalam database dengan metode FLANN.

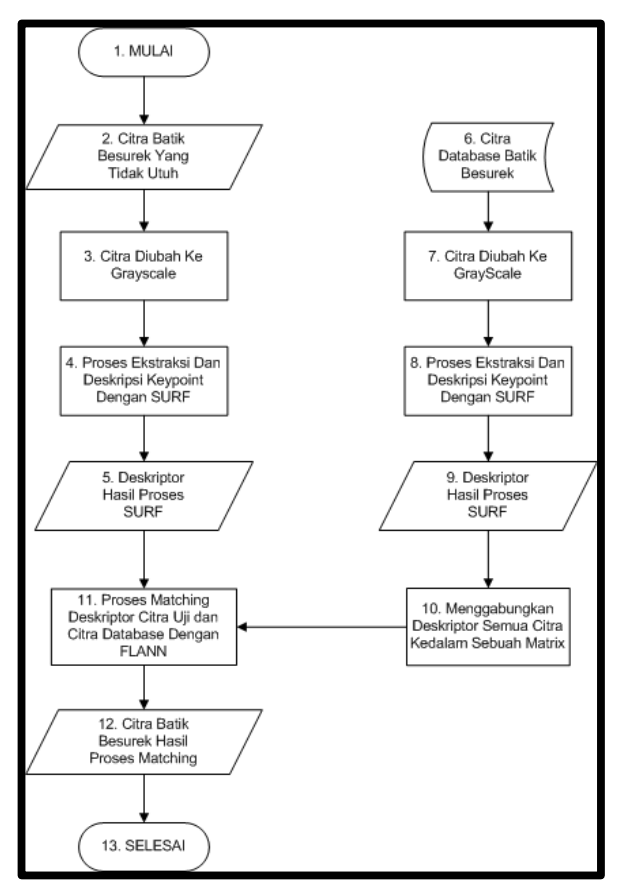

Gambar 5. Diagram Alir Sistem Temu Kembali Citra Batik Besurek Yang Tidak Utuh Menggunakan SURF

Berikut adalah diagram alir proses ekstraksi keypoint pada citra menggunakan metode Speeded Up Robust Features (SURF) yang dapat dilihat pada Gambar 6. Citra grayscale batik besurek akan dikonvolusi dengan turunan kedua Gaussian pada arah $x, y$, dan $x y$. Setelah itu akan dicari determinan hessian pada matriks hasil proses konvolusi sebelumnya, kemudian akan dilakukan proses threshold matriks hasil proses ini dengan nilai threshold yang digunakan adalah 300 .

Setelah itu akan dilakukan proses non-maxima suppression yang bertujuan untuk mendapatkan calon keypoint, dimana pada calon keypoint ini akan dilakukan proses interpolasi untuk mendapatkan keypoint. Keypoint yang didapat selanjutnya akan dideskripsikan menjadi deskriptor berdasarkan jumlah dari Haar Wavelet Responses.

Gambar 7 merupakan diagram alir proses matching dengan menggunakan metode Fast Library Approximated Nearest Neighbor (FLANN). Proses awal dari proses matching dengan FLANN ini adalah dengan menginputkan deskriptor hasil proses ekstraksi sebelumnya dimana akan dicari deskriptor yang sama pada citra uji dan citra didalam database, kemudian akan dicari 2 tetangga terdekat pada deskriptor tersebut. Selanjutnya akan dilakukan proses ratio distance dimana jika jarak tetangga terdekat pertama 0,8 kali jarak tetangga terdekat kedua, maka deskriptor tersebut sama, dan akan dilakukan proses penambahan jumlah deskriptor yang sama untuk citra tersebut. Proses ini dilakukan untuk semua citra di dalam database Setelah proses dilakukan untuk semua citra di dalam database, kemudian akan dilakukan perbandingan terhadap semua hasil deskriptor pada semua citra, dan akan ditampilkan citra yang memiliki nilai deskriptor yang sama terhadap citra uji yang paling besar. 
Jurnal Pseudocode, Volume V Nomor 2, September 2018, ISSN 2355-5920

www.ejournal.unib.ac.id/index.php/pseudocode

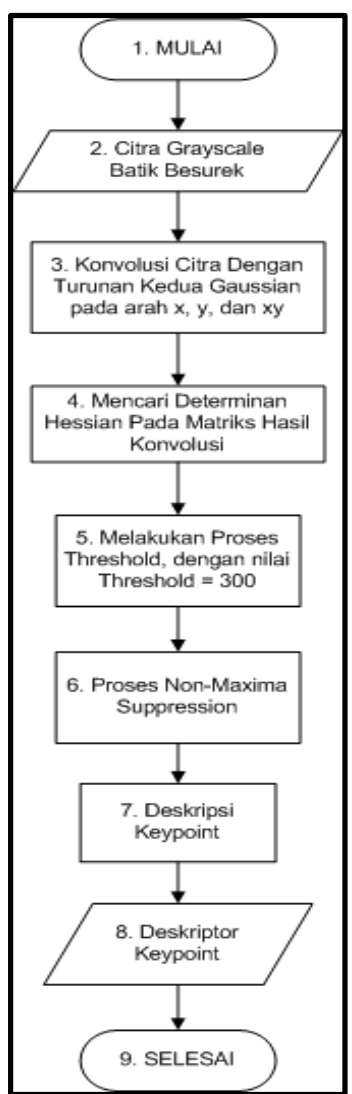

Gambar 6. Diagram Alir Proses Ekstraksi Keypoint dengan SURF

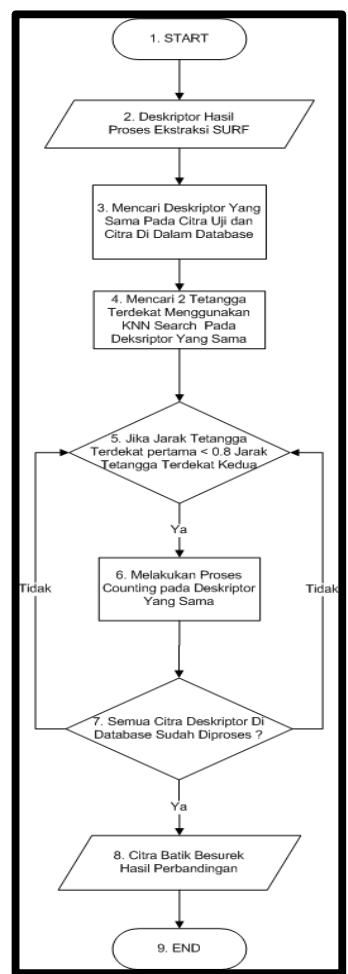

Gambar 7. Diagram Alir Proses FLANN

\section{PEMBAHASAN}

Adapun antarmuka untuk halaman utama aplikasi temu kembali citra batik besurek yang tidak utuh ini dapat dilihat pada Gambar 8.

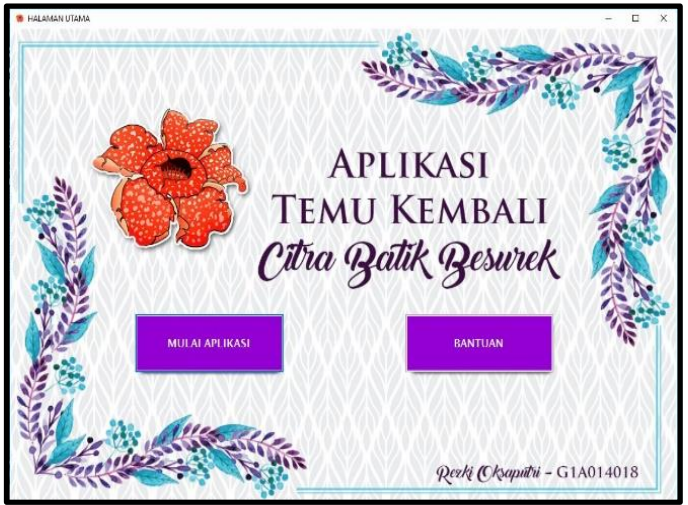

Gambar 8. Halaman Utama Aplikas

Aplikasi ini memiliki 2 halaman proses yaitu:

1. Halaman Proses Temu Kembali Citra:

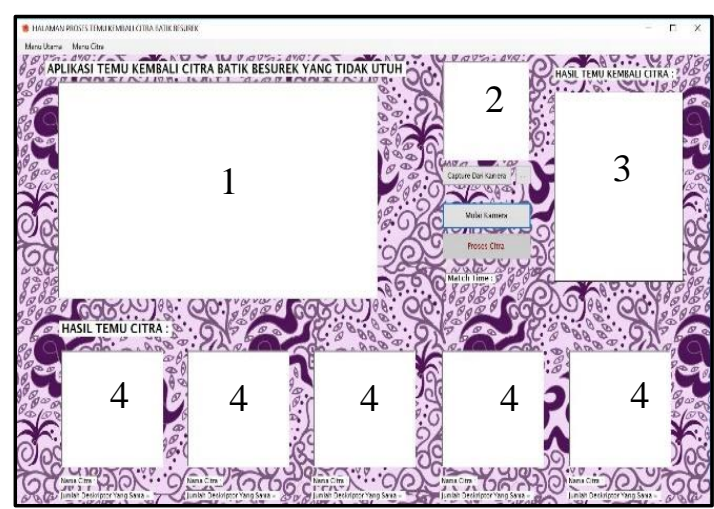

Gambar 9. Halaman Proses Temu Kembali

Halaman proses temu kembali ini merupakan halaman dimana dilakukan proses temu kembali citra batik besurek yang tidak utuh. Adapaun keterangan yang terdapat pada antarmuka pada Gambar 9. adalah:

$1=$ picturebox kamera.

2 = picturebox citra yang diinput (diproses menjadi citra grayscale.

3= Tabel menampilkan nama citra dan nilai deskriptor yang sama dari hasil temu kembali citra yang diinput.

$4=5$ hasil teratas dari perankingan hasil proses temu kembali. 
Jurnal Pseudocode, Volume V Nomor 2, September 2018, ISSN 2355-5920

www.ejournal.unib.ac.id/index.php/pseudocode

\section{Halaman Lihat Proses Matching}

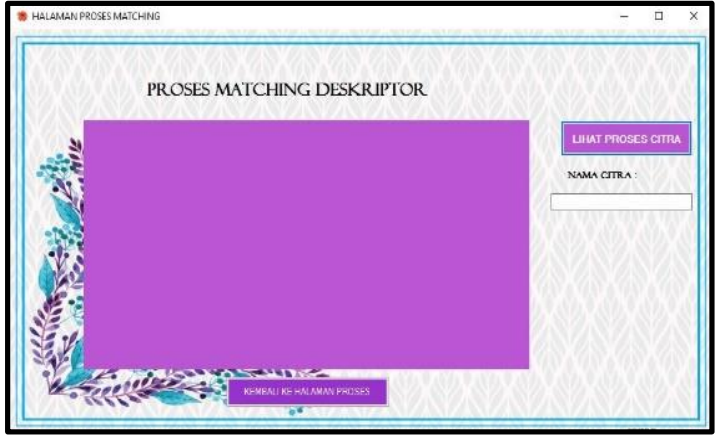

Gambar 10. Halaman Lihat Proses Matching

Halaman ini merupakan halaman untuk melihat hasil matching deskriptor antara citra uji dengan citra yang dipilih pada salah satu dari 5 citra teratas hasil proses temu kembali pada Gambar 10. Halaman ini akan menampilkan citra uji dan citra yang dipilih secara berdampingan dan akan ditarik garis untuk deskriptor yang sama pada kedua citra.

\section{HASIL PENGUJIAN}

Pengujian ini diawali dengan menginputkan citra batik besurek yang tidak utuh dan merubah citra tersebut menjadi citra grayscale seperti pada Gambar 11.

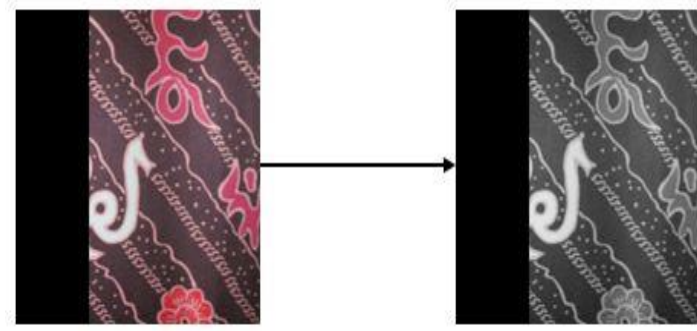

Gambar 11. Citra diubah menjadi citra grayscale

Setelah diubah menjadi citra grayscale, akan dilakukan proses ekstraksi dan deskripsi keypoint pada citra dengan menggunakan metode Speeded Up Robust Features (SURF). Hasil proses ekstraksi keypoint pada citra dengan menggunakan metode SURF ini dapat dilihat pada Gambar 12.

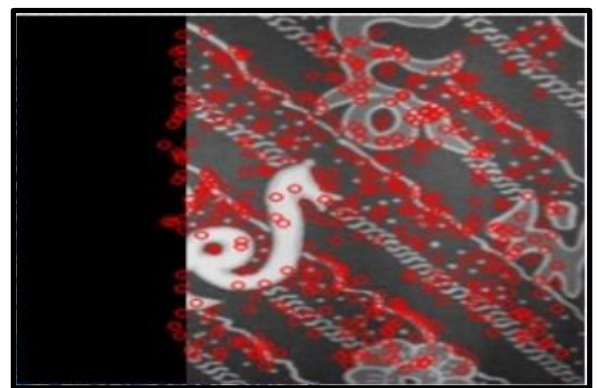

Gambar 12. Hasil Esktraksi Keypoint Citra

Kemudian, proses ekstraksi dan deskripsi keypoint juga akan dilakukan pada citra batik besurek di dalam database. Setelah itu akan dilakukan proses matching dengan menggunakan metode Fast Library Approximated Nearest Neighbor (FLANN), dimana parameter yang digunakan pada proses matching ini adalah keypoint yang telah dideskripsikan (deskriptor). Proses ini menggunakan KNN-search untuk mencari deskriptor yang sama, setelah itu dilakukan pencarian jarak terhadap 2 tetangga terdekat kemudian dilakukan proses rasio jarak terhadap jarak 2 tetangga terdekat tersebut. Digunakan nilai rasio $=0,8$ berdasarkan penelitian yang dilakukan oleh David G. Lowe dimana penelitiannya menolak semua kecocokan di mana rasio jarak lebih besar dari 0,8 yang menghilangkan 90\% kecocokan salah saat membuang kurang dari 5\% dari kecocokan yang benar, jika nilai rasio ini terpenuhi, maka akan dilakukan proses penambahan pada nilai jumlah deskriptor yang sama pada citra tersebut.

Hasil dari proses matching ini adalah nilai deskriptor yang sama pada setiap citra batik besurek di dalam database terhadap citra yang diinputkan, kemudian akan dilakukan proses perankingan terhadap nilai deskriptor yang sama. Hasil proses temu kembali ini dapat dilihat pada Gambar 13. 
Jurnal Pseudocode, Volume V Nomor 2, September 2018, ISSN 2355-5920

www.ejournal.unib.ac.id/index.php/pseudocode

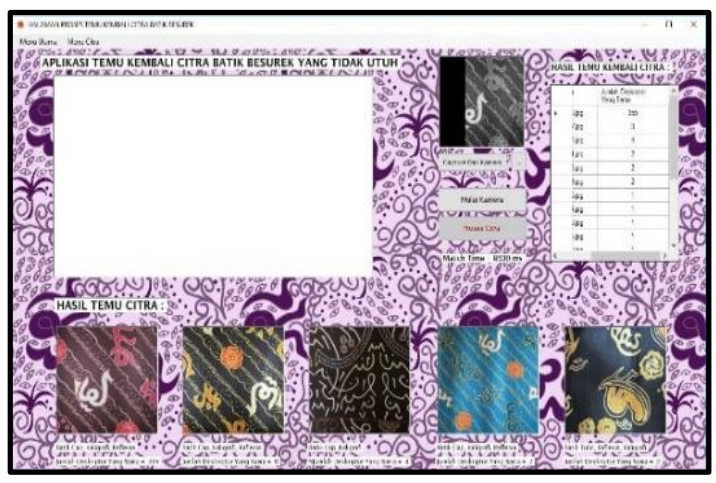

Gambar 13. Hasil Proses Temu Kembali

Setelah itu, dapat dilihat deskriptor yang sama pada citra uji dan citra yang dipilih dari 5 citra teratas yang ditampilkan. Pada Gambar 14. merupakan contoh lihat proses matching dengan citra yang dipilih merupakan citra ranking pertama pada Gambar 14. Gambar 14 menunjukkan deskriptor yang sama pada citra uji dan citra yang terpilih. Setelah itu, akan dihitung nilai recall, precision, dan akurasi menggunakan persamaan 4 , 5 , dan 6.

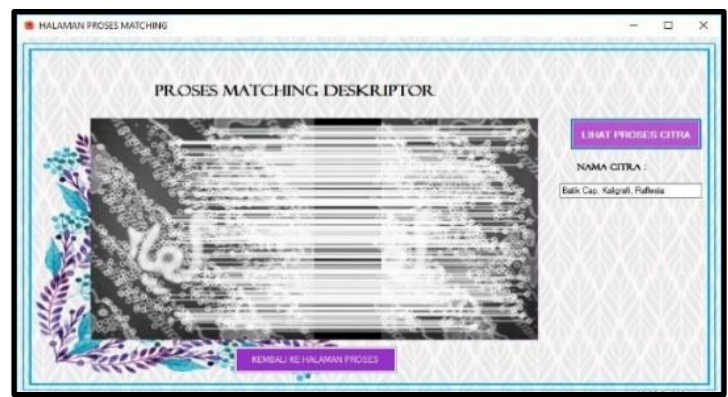

Gambar 14. Lihat Proses Matching Untuk Citra Ranking Pertama

Dengan menggunakan contoh pengujian pada Gambar 14, maka diketahui:

$R=53$

$R a=16$

$A=21$

Sehingga nilai recall dan precision-nya :

Recall $=\frac{16}{53}=0,302$

Precision $=\frac{16}{21}=0,762$
Sedangkan untuk nilai akurasi, diketahui bahwa nilai :

$T P=16 ; F P=5 ; F N=37 ; T N=9$

Sehingga nilai akurasi adalah :

$$
\begin{aligned}
\text { Akurasi }= & \frac{16+9}{16+5+37+9}=0,37 \\
& =0,37 \times 100=37 \%
\end{aligned}
$$

Nilai matchtime pada proses pengujian ini adalah $8930 \mathrm{~ms}=8,93$ detik .

Pengujian dilakukan dengan menggunakan 65 citra, dengan 54 citra merupakan citra batik besurek motif kaligrafi, raflesia, kaligrafi dan raflesia, burung kuau dan raflesia, burung kuau, dan rembulan yang ditutupi dari 10\% hingga $90 \%$ dengan menggunakan background berwarna hitam. Kemudian 5 citra yang berasal dari kain perca dengan motif kaligrafi dan raflesia, 3 citra dengan motif kaligrafi dan raflesia yang diambil dengan sudut pengambilan yang tidak baik, sehingga menyebabkan motif menjadi miring kedalam. Kemudian 3 citra dengan motif kaligrafi dan raflesia yang diambil dengan menggunakan kamera aplikasi. Kondisi citra batik besurek berada di dalam database adalah utuh dan diambil dengan baik sehingga memperlihatkan keseluruhan motif yang ada pada citra batik besurek tersebut. Nilai recall, precision, dan akurasi masing-masing motif berdasarkan pengujian yang telah dilakukan dapat dilihat pada Tabel 2.

Tabel 2. Nilai Recal, Precision, dan Akurasi MasingMasing Motif

\begin{tabular}{|c|c|c|c|c|}
\hline No & Nama Motif & Recall & Precision & Akurasi \\
\hline 1 & Kaligrafi & $44,44 \%$ & $17,74 \%$ & $75,0 \%$ \\
\hline 2 & Raflesia & $77,78 \%$ & $13,44 \%$ & $76,8 \%$ \\
\hline 3 & $\begin{array}{c}\text { Kaligrafi dan } \\
\text { Raflesia }\end{array}$ & $44,25 \%$ & $78.82 \%$ & $47,0 \%$ \\
\hline 4 & Burung Kuau & $77,78 \%$ & $13,36 \%$ & $84,7 \%$ \\
\hline 5 & $\begin{array}{c}\text { Burung Kuau } \\
\text { dan Raflesia }\end{array}$ & $88,89 \%$ & $16,67 \%$ & $80,6 \%$ \\
\hline 6 & Rembulan & $100 \%$ & $10,70 \%$ & $86,1 \%$ \\
\hline
\end{tabular}


Jurnal Pseudocode, Volume V Nomor 2, September 2018, ISSN 2355-5920

www.ejournal.unib.ac.id/index.php/pseudocode

Pada pengujian ini diketahui bahwa metode Speeded Up Robust Features dan Fast Library Approximated Nearest Neighbor (FLANN) dapat mengenali citra batik besurek dimana citra batik besurek yang ditutupi dari 10\% hingga $10 \%$.

\section{KESIMPULAN}

Berdasarkan pengujian yang telah dilakukan, maka dapat disimpulkan bahwa:

1. Metode Speeded Up Robust Features (SURF) dan Fast Library Approximated Nearest Neighbor (FLANN) dapat mengenali citra yang tidak utuh yang ditutupi $10 \%$ hingga $90 \%$.

2. Persentase rata-rata nilai recall dan precision adalah recall $=55,5 \%$ dan precision $=66,48 \%$. Waktu pengenalan citra batik besurek yang tidak utuh pada aplikasi ini adalah 7,767 detik.

3. Nilai recall terbesar dimiliki motif burung kuau dan raflesia yaitu sebesar $88,89 \%$ dan nilai precision terbesar dimiliki oleh motif kaligrafi dan raflesia yaitu $78.82 \%$.

\section{SARAN}

Berdasarkan analisis yang telah dilakukakan pada penelitian ini, terdapat beberapa saran yang dapat diberikan untuk pengembangan penelitian ini. Berikut saran yang dapat diberikan:

1. Pengembangan sistem yang selanjutnya diharapkan mampu untuk menyeleksi deskriptor yang cocok pada citra uji dan citra batik besurek yang ada di dalam database seperti dengan menggunakan metode sehingga mendapatkan hasil pengenalan yang lebih baik.

2. Sebaiknya deskriptor pada citra batik besurek disimpan ke dalam database sehingga dapat mengurangi waktu proses pencocokan.

\section{REFERENSI}

[1] A. Sumarna, "CBIR Berdasarkan Ekstraksi Fitur Warna Menggunakan Java," 2010.

[2] Y. Brasilka, Ernawati and D. Andreswari, "Klasifikasi Citra Batik Besurek Berdasarkan Ekstraksi Fitur Tekstur Menggunakan Jaringan Syaraf Tiruan Self Organizing Map (SOM)," Jurnal Rekursif, vol. 3, pp. 133-145, 2015

[3] D. B. Magfira, Ernawati and D. Andreswari, "Aplikasi Peningkatan Resolusi Citra Motif Batik Menggunakan Metode Interpolasi Spline Kuadratik (Studi Kasus: Citra Motif Batik Besurek Kota Bengkulu)," Jurnal Rekursif, vol. 3, pp. 123-131, 2015.

[4] Ernawati, K. Anggriani, F. F. Coastera and P. Primayana, "Deteksi Tepi Citra Batik Besurek Motif Gabungan Menggunakan Fuzzy Inferences System (Fis)," in Seminar Nasional Teknologi Informasi 2017, 2017.

[5] F. A. Lubis, H. Sunandar, G. L. Ginting and L. T. Sianturi, "Implementasi Metode Speed Up Features Dalam Mendeteksi Wajah," vol. 3, pp. 22-27, 2016.

[6] H. Kusumo, "Aplikasi Pengenalan Pola Citra Tanda Tangan Dengan Metode Speeded-Up Robust Features (SURF) Pada Single Board Computer Beaglebone Black," Skripsi, 2015.

[7] F. Yansyah, "Deteksi Wajah Menggunakan Metode SpeedUp Robust Features (SURF)," Skripsi, 2014.

[8] D. G. Lowe, "Distinctive Image Features from ScaleInvariant Keypoints," International Journal of Computer Vision, pp. 1-28, 2004.

[9] K. D. Tania, "Pengenalan Gambar Menggunakan Sebagian Data Gambar," Jurnal Generic, vol. 5, pp. 12-14, 2010. 